\title{
PROHIBITION OF DISCRIMINATION ON GROUNDS OF NATIONALITY IN THE FREEDOM OF MOVEMENT OF PERSONS WITHIN THE EU IN THE LIGHT OF CASE LAW OF THE COURT OF JUSTICE OF THE EUROPEAN UNION
}

\author{
Monika Bator-Bryta*
}

\begin{abstract}
The subject of this article is to analyze the meaning of the prohibition of discrimination on grounds of nationality in the light of the provisions of primary and secondary European Union law and the case law of the Court of Justice of the European Union, which is inherent to the functioning of the internal market and EU citizenship.

The prohibition of discrimination on grounds of nationality is undoubtedly one of the main goals of the European Union ${ }^{1}$ in the social and economic context, which was reflected in the localization of the matter in question in the primary law of the European Union ${ }^{2}$, in secondary law and in the jurisprudence of the Court of Justice of the European Union (CJEU). The Treaty on European Union (TEU) ${ }^{3}$
\end{abstract}

* Dr. Monika Bator-Bryła, Assistant Professor, Faculty of Law and Social Sciences, Jan Kochanowski University in Kielce; correspondence address: Świniary Stare 106A, 27670 Łoniów, Poland; e-mail: mbryla@ujk.edu.pl; https://orcid.org/0000-0003-1703-8040.

1 Cf. Olivier De Schutter, Links between migration and discrimination. A legal analysis of the situation in EU Member States (Brussels: European Commission, 2016), 102 and next; See also Brita Sundberg-Weitman, Discrimination on Grounds of Nationality. Free Movement of Workers and Freedom of Establishment under the EEC Treaty (Amsterdam, New York, Oxford: North-Holland Publishing Co., 1977).

2 Erica Szyszczak, "Antidiscrimination Law in the European Union," Fordham International Law Journal, no. 32 (2008): 635.

3 The Treaty on European Union (consolidated version) OJ of the EU 2012, No. C $326 / 01$. 
and the Treaty on the Functioning of the European Union $(T F E U)^{4}$ indicate equality as one of the EU values (Article $2 \mathrm{TEU}$ ), require it to be promoted and combat all discrimination (Articles 8 and 10 TFEU) and prohibit discrimination due to the criteria indicated therein (Articles 18 and 19 TFEU). In secondary law, this principle was expressed primarily in the Regulation of the European Parliament and of the Council No. 492/2011 on the free movement of workers within the Union and in art. 24 of Directive 2004/38/EC 2004 on the right of citizens of the Union and their relatives to move freely5.

A special role in this area is played by the case law of the Court of Justice of the European Union (CJEU), which stated that all authorities of the Member States are obliged to refuse to apply a provision of national law that is contrary to the prohibition of discrimination on the grounds of citizenship (Article 18 TFEU) ${ }^{6}$. Moreover, national measures may be examined in the light of art. 18 TFEU, but only to the extent that they apply to situations not covered by specific non-discrimination provisions included in the Treaty ${ }^{7}$.

The author puts forward the thesis that the analysis of CJEU jurisprudence reveals a visible dissonance between the application of national regulations of the Member States and the provisions of EU law in this matter, which significantly hinders the implementation of the principle of non-discrimination in practice. Discrepancies mainly occur in domestic legal acts due to the improper drafting of national legal provisions and / or their misinterpretation by national judicial or administrative authorities. It should be emphasized that the Member States are obliged to comply with EU law, which is not tantamount only to the obligation of state authorities to respect directly applicable acts, or to implement required regulations into internal law, but also the obligation to interpret and apply internal law in a manner that does not violate the requirement resulting from EU law ${ }^{8}$. Judicial

4 The Treaty on the Functioning of the European Union (consolidated version) OJ of the EU 2012, No. C 326/01.

5 Directive of the European Parliament and of the Council No. 2004/38 on the right of citizens of the Union and their family members to move and reside freely within the territory of the Member States amending Regulation (EEC) No. 1612/68 and repealing Directives 64/221/EEC, 68/360/EEC, 72/194/EEC, 73/148/EEC, 75/34/EEC, 75/35/EEC, 90/364/EEC, 90/365/EEC and 93/96/EEC (O.J.E.C. L 158, 30 April 2004).

6 CJEU Judgement of 7 May 1998, Clean Car Autoservice GmbH p. Landeshauptmann von Wien, Case C-350/96, ECLI:EU:C:1998:205.

CJEU Judgement of 18 June 2019, Republic of Austria v Federal Republic of Germany, Case C-591/17, ECLI:EU:C:2019:504, pt 41.

8 Marek Górski, "Wpływ orzecznictwa Europejskiego Trybunału Sprawiedliwości na interpretację i stosowanie przepisów o ochronie środowiska," in Wspólnotowe prawo ochrony 
and administrative authorities of the Member States should therefore interpret national law as far as possible, in line with EU law, because the limits of the proEU interpretation will be determined by the powers conferred by domestic law? The study uses the legal-comparative method, consisting in a comparative analysis of the legal systems of the Member States and the European Union in the field of non-discrimination on the basis of nationality, rights and restrictions on the freedom of movement of authorized entities. Comparative verification of EU acts with the internal standards of individual EU Member States allows to reveal the degree of advancement of the implementation process of EU law provisions under the free movement of EU citizens and their family members in the discussed area in the legal systems of European Union Member States. The purpose of this analysis is to, inter alia, diagnose areas in which these countries have not implemented or improperly implemented EU regulations, or have misinterpreted them.

The second method used is the method of analyzing the jurisprudence of the Court of Justice of the European Union - the rulings of the CJEU constitute a significant part of the study. The case law in question covers the period from the establishment of the Treaties of Rome to the present day. The use of the latter obligated the author to apply the comparative method of judgments based on same or similar legal bases in similar circumstances from different stages of the evolution of the free movement of citizens of the European Union and their family members under the prohibition of discrimination on the basis of nationality.

Keywords: prohibition, discrimination, nationality, European Union

\section{THE ESSENCE OF THE PROHIBITION OF DISCRIMINATION ON GROUNDS OF NATIONALITY}

The prohibition of discrimination on the basis of nationality is one of the fundamental concepts of freedom of movement ${ }^{10}$. It consists in equalizing the rights of citizens of the Member States who undertake any type

środowiska i jego implementacja w Polsce trzy lata po akcesji, ed. Jerzy Jendrośka and Magdalena Bar (Wrocław: Centrum Prawa Ekologicznego Press, 2008), 31.

9 Monika Niedźwiedź, "Stosowanie prawa wspólnotowego przez organy administracyjne," Casus, no. 32 (October 2004): 6.

10 Cf. Anne van der Mei, "The Outer Limits of the Prohibition of Discrimination on Grounds of Nationality: A Look through the Lens of Union Citizenship," Maastricht Journal of European and Comparative Law 18, Issue 1-2 (March 2011): 63 and next. 
of professional activity in the territory of another Member State. In the EU legal system, equality was introduced on the basis of treaty provisions prohibiting discrimination, and therefore differently than in most constitutional legal systems of the Member States. In fact, the Court of Justice has stated in a number of judgments that the prohibitions of discrimination in the Treaty are only a specific expression of the general principle of equality, which is one of the fundamental principles of EU law ${ }^{11}$. It should be emphasized that the Court of Justice of the EU uses interchangeably the concepts of "the principle of equal treatment" and "the principle of non-discrimination", which was confirmed, inter alia, in the judgment of case C-422/02 ${ }^{12}$. We are dealing here with two terms of the same general principle of EU law, which, on the one hand, forbids different treatment of similar situations, and on the other hand, to treat different situations in the same way, unless there are objective reasons justifying such diverse treatment ${ }^{13}$.

The prohibition of discrimination on grounds of nationality applies in particular to the right to free movement and stay in the territory of a Member State, in particular with regard to remuneration, taxation, social affairs, education and all other spheres affecting the legal status of EU citizens and members of their families ${ }^{14}$. The comprehensive application of this principle in many areas of life has obliged the legislators of the Member States to include it in national acts of statutory rank.

It should be emphasized that the principle of non-discrimination does not mean that it is impossible to impose specific requirements on foreigners $^{15}$. The authorities of individual states cannot place conditions only

11 Justyna Maliszewska-Nienartowicz, "Rola zasady równości w prawie Wspólnoty/ Unii Europejskiej," Studia Europejskie, no. 4 (2011): 73.

12 CJEU Judgement of 27 January 2005, Europe Chemi-Con (Deutschland) GmbH v Council of the European Union, Case C-422/02, ECLI:EU:C:2005:56.

13 Justyna Maliszewska-Nienartowicz, "Rola zasady równości w prawie Wspólnoty/ Unii Europejskiej," Studia Europejskie, no. 4 (2011): 74.

14 Władysław Czapliński, Zarys prawa europejskiego (Warsaw: Hesińska Fundacja Praw Człowieka, 1999), 57; see CJEU Judgement of 25 October 2012, Déborah Prete v Office national de l'emploi, Case C-367/11, ECLI:EU:C:2012:668.

15 Leszek Mitrus, "Ewolucja prawa unijnego w dziedzinie swobody przemieszczania pracowników," in Prawo pracy w świetle procesów integracji europejskiej. Księga jubileuszowa 
discriminatory on grounds of nationality in relation to the requirements applicable to the nationals performing the same type of work. Anyone who holds the nationality of a Member State is an EU citizen, while the status of Union citizen is the fundamental status of nationals of the Member States ${ }^{16}$. Moreover, it allows the same treatment to be enjoyed from a legal point of view, irrespective of nationality and without prejudice to exceptions expressly provided for in that regard ${ }^{17}$.

\section{LEGAL BASIS OF DISCRIMINATION ON GROUNDS OF NATIONALITY}

Among the treaty provisions relating directly to the prohibition of discrimination on grounds of nationality, the most important is the non-discriminatory clause, currently provided for in Art. 18 TFEU, referring to the criterion of nationality. And so, in the light of Art. 18 TFEU within the scope of application of the Treaties, and without prejudice to any special provisions contained therein, any discrimination on grounds of nationality shall be prohibited.

The legal basis of this principle has been regulated both in primary and secondary law of the European Union. Article 18 TFEU is a general prohibition of discrimination on grounds of nationality ${ }^{18}$,

Profesor Marii Matey-Tyrowicz, ed. Jerzy Wratny and Magdalena Barbara Rycak (Warsaw: Wolters Kluwer, 2011), 138.

16 CJEU Judgement of 17 September 2002, Baumbast and R v Secretary of State for the Home Department, Case C-413/99, ECLI:EU:C:2002:493, pt 82; Aleksandra Czekaj, "Glosa do orzeczenia ETS z dnia 17.09.2002r. w sprawie C-413/99, Baumbast i R. v Secretary of State for the Home Department," Problemy Wspótczesnego Prawa Międzynarodowego, Europejskiego i Porównawczego 2 (2004): 186-195.

17 CJEU Judgement of 20 September 2001, Rudy Grzelczyk v Centre public d'aide socjale d'Ottignies- Louvain- la- Neuve, Case C-184/99, ECLI:EU:C:2001:458, pt 30 and 31; CJEU Judgement of 2 October 2003, Carlos Garcia Apellov Belgian State, Case C-148/02, ECLI:EU:C:2003:539, pt. 22 and 23.

18 See also Evelien Brouwer and Karin de Vries, "Third-country nationals and discrimination on the ground of nationality:article 18 TFEU in the context of article 14 ECHR and EU migration law: time for a new approach," in Equality and human rights: nothing but trouble?, eds. Marjolein Van den Brink, Susanne Burri, and Jenny Goldschmidt (Utrecht: SIM, 2015), 123 and next; Thomas Cottier and Matthias Oesch, "Direct and Indirect 
while Art. 45 sec. 2 TFEU covers the elimination of discrimination on grounds of nationality between workers from the Member States as regards to employment, remuneration and other working conditions. While Art. $18 \mathrm{TFEU}$ is general in nature and applies in cases where there are no specific provisions prohibiting discrimination on the basis of nationality, Art. $45 \mathrm{sec} .2$ TFEU is a lex specialis with reference to Art. 18 TFEU. In this regard, it should be recalled that Art. 18 TFEU, which establishes the general principle of non-discrimination on grounds of nationality, can be applied alone only in situations governed by EU law for which the Treaty does not contain specific non-discrimination provisions ${ }^{19}$.

The Charter of Fundamental Rights of the European Union (EU Charter of Fundamental Rights) has also become a source of non-discrimina$\operatorname{tion}^{20}$, regulating equality before the law and regulating the catalog of forbidden grounds for discrimination. The EU Charter was made binding on the basis of the Lisbon Treaty ${ }^{21}$, which significantly strengthened the rights of the individual in the field of equality before the law and non-discrimination.

Article 21 paragraph. 1 of the Charter states that "Any discrimination based on any ground such as sex, race, colour, ethnic or social origin, genetic features, language, religion or belief, political or any other opinion, membership of a national minority, property, birth, disability, age or sexual orientation shall be prohibited'. Article catalog 21 of the Charter contains an open list

Discrimination in WTO Law and EU Law,” Working Paper, no. 2011/16 (April 2011): 12; Sonia Morano-Foadi, "Third Country Nationals Versus EU Citizens: Discrimination Based on Nationality and the Equality Directives," Oxford Brookes University - School of Social Sciences and Law (December 2010).

19 CJEU Judgement of 18 June 2019, Republic of Austria v Federal Republic of Germany, Case C-591/17, ECLI:EU:C:2019:504, pt 39; CJEU Judgement of 18 July 2017, Konrad Erzberger vTUI AG., Case C-566/15, ECLI:EU:C:2017:562, pt 25; CJEU Judgement of 4 September 2014, Schiebel Aircraft GmbH v Bundesminister für Wirtschaft, Familie und Jugend, Case C-474/12, ECLI:EU:C:2014:2139, pt 20.

20 EU (2000) Charter of Fundamental Rights of the European Union, 2000/C 361/01, 7 December 2000.

21 The Treaty of Lisbon, 2007/C O.J. 306, 17 December 2007. 
of prohibited discriminatory grounds, contrary to Art. $19 \mathrm{TFEU}^{22}$, which is an exhaustive list of anti-discrimination bans.

It should be emphasized that the Charter guarantees protection only against violations of the principles of equality and non-discrimination resulting from the actions of the institutions, bodies, offices and agencies of the Union and the Member States to the extent that they apply EU law (Article 51 of the Charter), because its purpose was not to create new rights, but to confirm the rights recognized by EU law.

In secondary law, this principle was expressed, inter alia, in Regulation No. 492/2011 of the European Parliament and of the Council ${ }^{23}$ and in Art. 24 of Directive 2004/38/EC on the right of citizens of the Union and their relatives to move freely ${ }^{24}$. The former states that it is not possible to apply laws, regulations, administrative acts or administrative practices limiting the right to apply for employment or submit job offers. Moreover, the EU law imposes compliance with prohibition of discrimination on the grounds of nationality by every national entity that applies or establishes the law. Unfortunately, the verification of the selected case law of the CJEU shows a visible dissonance between the norms of EU law and the regulations of individual Member States.

An important right of employees moving within the $\mathrm{EU}$ is the right to work in the host country, specified in Art. 7-9 of Regulation 492/11. The Treaty on the Functioning of the European Union itself, in Art. 45 sec. 2 defines indirectly, through the wording "the abolition of any discrimination based on nationality between workers of the Member

22 Art. 19 sec. 1 TFEU is a provision of competence which authorizes the EU to adopt legal acts that implement the treaty guidelines in the field of combating discrimination. On the basis of this provision there were issued, inter alia, so-called. EU equality directives. The Treaty on the Functioning of the European Union (consolidated version), 2012/C O.J. 326, 26 October 2012.

${ }_{23}$ Regulation of the European Parliament and of the Council No. 492/2011 on the free movement of workers within the Union (O.J.E.C L141, 5 April 2011).

24 Directive of the European Parliament and of the Council No. 2004/38 on the right of citizens of the Union and their family members to move and reside freely within the territory of the Member States amending Regulation (EEC) No. 1612/68 and repealing Directives 64/221/EEC, 68/360/EEC, 72/194/EEC, 73/148/EEC, 75/34/EEC, 75/35/EEC, 90/364/EEC, 90/365/EEC and 93/96/EEC (O.J.E.C. L 158, 30 April 2004). 
States as regards employment, remuneration and other conditions of work and employment", the right to work in another Member State. It seems that the terms of national law, applicable regardless of nationality, will be considered indirectly discriminatory if they primarily affect migrant work$\mathrm{ers}^{25}$ or the great majority of migrant workers ${ }^{26}$. The attribute of indirect discrimination will also be achieved by criteria that will be more easily met by domestic workers than by migrants ${ }^{27}$ or requirements that may affect the latter ${ }^{28}$. The CJEU emphasized that the national regulation should be objectively justified and proportionate to the aim pursued, in order to exclude its discriminatory character. Moreover, it does not have to affect a specific group of entities. It is enough that it can have such an effect ${ }^{29}$.

25 "Accordingly, conditions imposed by national law must be regarded as indirectly discriminatory where, although applicable irrespective of nationality, they affect essentially migrant workers-CJEU Judgement of 15 January 1986, Pinna v Caisse d' Allocations Familiales de la Savoie, ECLI:EU:C:1986:1, pt 24; CJEU Judgement of 30 May 1989, Alluè and Another v Universitá degli Studi di Venezia, Case C-33/88, ECLI:EU:C:1989:222, pt 12; CJEU Judgement of 21 November 1991, Union de Recouvrement des Cotisations de Sécurité Sociale et d'Allocations Familiales de la Savoie (URSSAF) v Hostellerie Le Manoir SARL, Case C-27/91, ECLI:EU:C:1991:441, pt 11.

26 CJEU Judgement of 17 November 1992, Commission v United Kingdom, Case C-279/89, ECLI:EU:C:1992:439, pt 42; CJEU Judgement of 20 October 1993, Spotti v Freistaat Bayern, Case C-272/92, ECLI:EU:C:1993:848, pt 18.

27 "...where they are indistinctly applicable but can more easily be satisfied by national workers than by migrant workers" - CJEU Judgement of 10 March 1993, Case C-111/91, Commission of the European Communities v Grand Duchy of Luxembourg, ECLI:EU:C:1993:92, pt 10; CJEU Judgement of 4 October 1991, Elissavet Paraschi v Landesversicherungsanstalt Württemberg, Case C-349/87, ECLI:EU:C:1991:372, pt 23. Such a situation will be the case for a residence requirement which will be easier for national workers than for nationals of other Member States - see CJEU Judgement of 8 June 1999, C.P.M. Meeusen v Hoofddirectie van de Informatie Beheer Groep, Case C-337/97, ECLI:EU:C:1999:284, pt 23 and 24.

28 "...where there is a risk that they may operate to the particular detriment of migrant workers” - CJEU Judgement of 8 May 1990, Klaus Biehl v Administration des contributions du grand-duché de Luxembourg, Case C-175/88, ECLI:EU:C:1990:186, pt 14; CJEU Judgement of 28 January 1992, Hanns-Martin Bachmann v Belgian State, C-204/90, ECLI:EU:C:1992:35, pt 9.

29 CJEU Judgement of 23 May 1996, John O'Flynn v Adjudication Officer, Case C-237/94, ECLI:EU:C:1996:206, pt 19-21; CJEU Judgement of 21 September 2000, Carl Borawitz v Landesversicherungsanstalt Westfalen, Case C-124/99, ECLI:EU:C:2000:485, 
The prohibition of discrimination against nationals of the Member States is the subject of many regulations of EU law. Art. 7 sec. 1 of Regulation 492/2011 of 5 April 2011 regulates the status of an employee with the citizenship of a Member State, who, due to their nationality, should be treated on the territory of the host country on an equal basis with the nationals in terms of employment and work conditions ${ }^{30}$, mainly with regard to remuneration and termination, and in the event of becoming unemployed, reinstatement or re-employment. The principle of equality also covers social benefits and tax relief (Article $7 \mathrm{sec}$. 2) ) $^{31}$, access to training in vocational schools and in-service training centers (Article $7 \mathrm{sec} .3$ ). The prohibition of discrimination on the basis of nationality also applies in the area of the social security system ${ }^{32}$. The migrant worker is therefore entitled to the same social rights and tax benefits as a domestic work$\mathrm{er}^{33}$. The concept of social and tax benefits contained in Art. 7 sec. 2 of the above-mentioned regulation, is in close relation to all rights related to the employment relationship, as evidenced by the location of the provision in the chapter "Employment and equality of treatment" 34 .

The Treaty on the Functioning of the European Union creates a topdown prohibition of discrimination against nationals of other Member States in the field of social rights. The essence of EU provisions on social security law is the guarantee of the acquisition and retention of certain benefits by people who enjoy the freedom of movement in other Member States.

pt 26-27; CJEU Judgement of 28 April 2004, Sakir Öztürk v Pensionsversicherungsanstalt der Arbiter, Case C-373/02, ECLI:EU:C:2004:232, pt 57.

30 CJEU Judgement of 5 December 2013, Zentralbetriebsrat der gemeinnützigen Salzburger Landeskliniken Betriebs GmbH v Land Salzburg, Case C-514/12, ECLI:EU:C:2013:799, pt 45.

31 CJEU Judgement of 21 February 2013, L.N. v Styrelsen for Videregående Uddannelser og Uddannelsesstøtte C-46/12, ECLI:EU:C:2013:97, pt 49-51.

32 See also Frans Pennings, "Non-Discrimination on the Ground of Nationality in Social Security: What are the Consequences of the Accession of the EU to the ECHR?," Utrecht Law Review 9, Issue 1 (January 2013): 118.

33 Evelyn Ellis, "Social advantages: a new lease of life?," Common Market Law Review 40 (2003): 639.

34 Francesco Rossi Dal Pozzo, Citizenship rights and freedom of movement in the European Union (the Netherlands: Kluwer Law International Press, 2013), 109. 
In light of Art. 1 of Regulation 492/2011, every EU citizen has the right to start employment in the territory of another Member State. They have the right to access the labor market under the same conditions as nationals. In the case of Union nationale des entraineurs et cadres techniques professionnels du football (Unectef) v. Georges Heylens and others, the CJEU recognized freedom of access to employment as a fundamental element for every worker ${ }^{35}$. This is ensured primarily by the principle of equal treatment established in Art. 18 TFEU and the European Convention for the Protection of Human Rights and Fundamental Freedoms ${ }^{36}$. However, Article 18 TFEU, as R. Babayev argued, goes beyond the mere prohibition of discrimination on the basis of nationality ${ }^{37}$.

Proper implementation of the right to move within the territory of the European Union obliges a state to apply the prohibition of discrimination in relation to EU citizens and their family members who use the right to migrate. A. Zawidzka-Łojek rightly argues that ensuring the general principle of equality should not be limited to the elimination of measures leading to unjustified, unequal treatment, but should also mean taking affirmative actions, resulting in equalizing the situation of entities treated less favorably with the best applied standard ${ }^{38}$. The CJEU confirmed that internal regulations, which put citizens of a given state in a worse position only because they exercised the right to migrate and stay in another Member State, constitute an obstacle to the freedoms guaranteed by Art. 18 TFEU to every EU citizen ${ }^{39}$.

35 CJEU Judgement of 15 October 1987, Union nationale des entraîneurs et cadres techniques professionnels du football (Unectef) v Georges Heylens and others, Case C-222/86, ECLI:EU:C:1987:442.

36 Christopher McCrudden and Sacha Prechal, The concepts of Equality and non-discrimination in Europe. A practical Approach (Brussels: European Network of Legal Experts in the Field of Gender Equality, 2009), 2.

37 See Rufat Babayev, Choice of the applicable law and equal treatment in the European Union (Durham: Durham University, 2012), 93.

38 Anna Zawidzka - Łojek, Zakaz dyskryminacji ze względu na wiek w prawie Unii Europejskiej (Warsaw: Instytut Wydawniczy EuroPrawo, 2013), 40.

39 CJEU Judgement of 11 July 2002, Marie-Nathalie D'Hoop v. Office national de l'emploi, Case C-224/98, ECLI: ECLI:EU:C:2002:432, pt 31; CJEU Judgement of 29 April 2004, Heikki Antero Pusa v. Osuuspankkien Keskinäinen Vakuutusyhtiö, Case C-224/02, ECLI:EU:C:2004:273, pt 19. 


\section{EMPLOYMENT IN PUBLIC ADMINISTRATION}

An important category of derogation from the prohibition of discrimination on grounds of nationality, justifying the application of restrictions on the grounds of protection of the interests of a Member State, is employment in public administration. The issue of "employment in public administration" is regulated by Art. $45 \mathrm{sec} .4$ of the Treaty on the Functioning of the European Union, but not specifying its scope ${ }^{40}$. It is true that Art. $45 \mathrm{sec} .2$ TFEU states that the free movement of workers includes the elimination of all discrimination on grounds of nationality between workers of the Member States as regards to employment, remuneration and other conditions of work, however, Art. 45 sec. 4 TFEU emphasizes that the provisions of this article do not apply to employment in the public administration. This means that Member States may restrict access to certain posts in public administration in a situation where their national interests need to be protected.

There is no doubt that the interpretation of the above concept should be made on the basis of EU law due to the need for uniform implementation in the Member States. It would be irrational to be allowed to work in a certain position in the civil service in a given country, while there is no such possibility for the same position in another country. This means that it is impossible to base its scope solely on the norms of national law ${ }^{41}$. It is certain that one of the purposes of such an interpretation is the full implementation of the provisions of the Treaty, avoiding a restrictive application of the term 'public administration', created by the regulations of national law ${ }^{42}$. M.K. Kolasiński emphasizes that the competence to define the concept of employment in public administration rests with the EU courts and not with the Member States ${ }^{43}$. The literature rightly emphasizes

40 Francesco Rossi Dal Pozzo, Citizenship rights and freedom of movement in the European Union (the Netherlands: Kluwer Law International Press, 2013), 116.

${ }^{41}$ CJEU Judgement of 30 September 2003, Albert Anker, Klaas Ras and Albertus Snoek v. Bundesrepublik Deutschland, Case C-47/02, ECLI:EU:C:2003:516, pt 57.

42 Ludwik Florek, Europejskie prawo pracy (Warsaw: LexisNexis Press, 2010), 55.

43 Marek Krzysztof Kolasiński, "Odmienności związane z zatrudnieniem w administracji publicznej," in Zarys prawa swobód rynku wewnętrznego Unii Europejskiej, ed. Marek Krzysztof Kolasiński (Toruń: Dom Organizatora Press, 2013), 165. 
the differentiation between the concept of 'employment in the public service' and the concept used in the Polish version of the TFEU 'employment in public administration' ${ }^{44}$.

Some case-law, in particular the judgment in the case The Commission of the European Communities $v$ Kingdom of Belgium ${ }^{45}$, is relevant in this respect. In this case, the EC Commission accused the Belgian authorities of introducing a Belgian nationality requirement for positions not covered by Art. 39 sec. 4 of the EC Treaty (Article 45 (4) TFEU), due to the lack of links between the latter and actual participation in the exercise of official authority or national interests, especially in the field of security. There is no doubt that the scope of application of the first three paragraphs is mutually exclusive with the fourth paragraph of Art. 45 TFEU. The last paragraph includes particularly sensitive positions due to the specific type of bond and loyalty of a citizen to their own state. Moreover, the CJEU has repeatedly emphasized in its jurisprudence the attribute of the primacy of EU law in relation to national standards, because the opposite situation would allow freedom in the application of EU regulations by the Member States. In response to the arguments of the Belgian authorities, referring, inter alia, to art. 8 of Regulation 1612/68/EEC (currently Regulation No 492/2011 of 5 April 2011) that the derogation provided for in par. 4 of the above-mentioned provision was general and covered all positions in the administration of a given member state, it should be emphasized that the above standard does not impose an obligation, but gives the possibility of excluding from participation in the management board of public law institutions and from holding offices regulated by public law. On the other hand, it seems unacceptable to refer to national regulations aimed at any limitation of the norms of Community law, because the limits and scope of Art. $45 \mathrm{sec} .4 \mathrm{TFEU}$ is determined by the provisions at the EU level, taking into account the interest of the Member State in the form of reserving a specific group of positions related to the exercise of official authority

44 Monika Smusz-Kulesza, “Ograniczenia swobody przepływu pracowników," in Swobodny przeptyw pracowników wewnątrz Unii Europejskiej, ed. Zbigniew Hajn (Warsaw: EuroPrawo Press, 2010), 119.

45 CJEU Judgement of 17 December 1980, The Commission of the European Communities v Kingdom of Belgium, Case C-149/79, ECLI:EU:C:1982:195. 
for their own citizens. In the discussed dispute, the CJEU did not issue an unequivocal decision, because it did not specify the actual nature of the tasks falling within the scope of the positions of the cases under review and did not determine which of them were not covered by Art. $39 \mathrm{sec} .4$ of the EC Treaty (Article 45 (4) TFEU). As it was not possible to find any failure on the part of the Belgian authorities, the CJEU referred the case for reconsideration. On the other hand, the breach of obligations under Art. 39 sec. 4 was confirmed in the case The Commission of the European Communities $v$ French Republic $c^{46}$. The breach of the latter was based on the acceptance in national legislation a requirement of French nationality in relation to the positions of captains and officers, flying the French flag. Similar circumstances occurred in The Commission of the European Communities v Italian Republic case $e^{47}$. The Commission's complaint concerned Italian legislation which made the performance of the duties of captain and deputy captain on all Italian-flagged vessels subject to the condition of having Italian nationality ${ }^{48}$. In this case, the Court ruled on the inadmissibility of the implementation of national provisions that negate the fundamental civil liberties granted by the EC Treaty ${ }^{49}$. It should be remembered that the protection of fundamental rights is a fundamental principle of the Union, which is a necessary condition for the legality of all activities undertaken within the framework of EU law. This creates on the part of the Member States both an individual and collective obligation to protect, act and cooperate in this matter ${ }^{50}$.

Specification of the material scope of Art. 45 sec. 4 TFEU causes particular difficulties in certain situations, as the Member States do not have

46 CJEU Judgement of 11 March 2008, The Commission of the European Communities v French Republic, Case C-89/07, ECLI:EU:C:2008:154.

47 CJEU Judgement of 11 September 2008, The Commission of the European Communities v Italian Republic, Case C-447/07, ECLI:EU:C:2008:502.

48 CJEU Judgement of 30 September 2003, Colegio de Oficiales de la Marina Mercante Española v Administración del Estado, Case C-405/01, ECLI:EU:C:2003:515.

49 CJEU Judgement of 10 December 2009, Commission of the European Communities v Hellenic Republic, Case C-460/08, ECLI:EU:C:2009:774.

50 Guy S. Goodwin-Gill, "Migration: International Law and Human Rights," in Managing Migration: Time for a New International Regime?, ed. Bimal Gosh (Oxford: Oxford University Press, 2000), 196. 
the same state administrative structure. Determining whether a given position is related to the exercise of public authority should be based on unambiguous criteria, qualifying it or disqualifying it as those related to the exercise of power in public authorities. The lack of a uniform interpretation of the above-mentioned issues often results in an incorrect understanding of the scope of the positions covered by paragraph 4 of Art. 45 TFEU and the functioning of defective or inconsistent regulations of national law inconsistent with EU law.

As L. Mikrus rightly emphasized, although the CJEU recognized the competence of the Member States to independently define internal administrative structure, it did not leave them any freedom to specify the scope of employment in public administration. Moreover, Art. $45 \mathrm{sec} .4$ TFEU covers only those positions which are directly or indirectly related to the exercise of state power ${ }^{51}$. The criterion for the application of the said provision is therefore the condition of direct or indirect participation in the exercise of power and the protection of the general interests of the state or public authorities ${ }^{52}$. Only in the event of the occurrence of both conditions jointly, there is a basis for reserving employment in public administration for a state's own citizens. Moreover, the Tribunal emphasized the impossibility of limiting access to employment in the administration in the event that public powers are exercised sporadically or constitute an insignificant element of the general activity performed under a given position ${ }^{53}$.

As evidenced by settled case law, the difficulties are not caused by the determination and classification of positions consisting in direct exercise of power, but by the question of indirect participation in it, because the latter poses a threat in the form of implementation of individual national regulations, extending the scope of Art. $45 \mathrm{sec} .4$ TFEU. Therefore, the Court seeks a restrictive interpretation of this concept. There are many

51 Leszek Mitrus, Swoboda przemieszczania się pracowników po przystąpieniu Polski do Unii Europejskiej (Cracow: LexisNexis Press, 2003), 243.

52 CJEU Judgement of 17 December 1980, The Commission of the European Communities v Kingdom of Belgium, Case C-149/79, ECLI:EU:C:1982:195, pt 10.

53 CJEU Judgement of 30 September 2003, Colegio de Oficiales de la Marina Mercante Española v Administración del Estado, Case C-405/01, ECLI:EU:C:2003:515, pt 44-45. 
positions in the field of public service that are not directly related to the exercise of national sovereignty. Therefore, it is not necessary to reserve them solely for the benefit of the citizens of the host country. The restriction of exclusive access to the public service should be applied to the necessary minimum.

The analysis of the CJEU jurisprudence leads to the conclusion that the concept of "indirect participation in the exercise of public authority" is not precisely defined, therefore the possible classification of administrative powers within the scope of $45 \mathrm{sec}$. 4 TFEU creates many difficulties for the competent national authorities. In this situation, it seems necessary to assess each case individually, taking into account the type of activities performed and the nature of the position.

There is also no doubt that the unjustified application of Art. $45 \mathrm{sec}$. 4 TFEU by the authorities of the Member States will constitute a breach of the prohibition of discrimination on grounds of nationality.

\section{CASE LAW OF THE CJEU}

\subsection{Case James Wood v Fonds de garantie des victimes des actes de terrorisme et d'autres infractions}

The jurisprudence of the Court of Justice of the EU plays an important role in the implementation of the prohibition of discrimination on grounds of nationality. In the case of James Wood $v$ Fonds de garantie des victimes des actes de terrorisme et d'autres infractions (guarantee fund for victims of terrorist activities and other crimes) ${ }^{54}$ there was a different treatment, based solely on nationality criterion, because an entity was excluded from the circle of persons entitled to compensation solely because of the citizenship of another Member State. A British citizen concerned was denied, based on Article. 706 paragraph 3 code de procédure pénale

54 CJEU Judgement of 5 June 2008, James Wood v Fonds de garantie des victimes des actes de terrorisme et d'autres infractions, Case C-164/07, ECLI:EU:C:2008:321. 
(French Code of Criminal Procedure) ${ }^{55}$, compensation for the loss of his daughter, despite the fulfillment of financial claims in this regard to his concubine, holding French citizenship. The provision in question introduced the requirement of French nationality in order to obtain compensation on the fulfillment of the French nationality condition. The CJEU confirmed, that community law precludes legislation of a Member State which excludes nationals of other Member States who live and work in its territory from the grant of compensation intended to make good losses resulting from offences against the person where the crime in question was not committed in the territory of that State, on the sole ground that they do not have the nationality of that State.

A particular expression of compliance with the principle of equal treatment is Art. $45 \mathrm{sec} .2$ TFEU, which requires the application of the above rule in the area of employment, remuneration and other working conditions in relation to employees of the Member States ${ }^{56}$. The essence of the aforementioned rule is the same treatment of entities in comparable situations, because otherwise, as mentioned, except for the existence of objective premises, discrimination occurs. Therefore, in conflict with EU law are the provisions of a Member State that exclude nationals of other Member States from the circle of persons entitled to compensation for personal injury and compensation for harm caused by an offense not committed on its territory solely because of their nationality ${ }^{57}$ or national regulations allowing for refusal to recognize rights acquired from the date of first employment with consequences in terms of remuneration, length of service and payment of social security contributions by the employer, if a national worker in a comparable situation would be entitled to such recognition ${ }^{58}$.

55 The article modified by Act No. 2004-204 of 9 March 2004, art.169 Official Journal of 10 March 2004, in force 1 January 2005.

56 CJEU Judgement of 2 August 1993, Beatrice Sellinger, RosalbaDel Maestro, Gillian Mansfield v Università degli Studi di Parma, Case C-332/91, ECLI:EU:C:1993:333.

57 CJEU Judgement of 5 June 2008, James Wood v Fonds de garantie des victimes des actes de terrorisme et d'autres infractions, Case C-164/07, ECLI:EU:C:2008:321, pt 17.

58 CJEU Judgement of 15 May 2008, Nancy Delay v Universitá degli studi di Firenze and others, Case 276/07, ECLI:EU:C:2008:282, pt 31. 


\subsection{Case Dany Bidar v London Borough of Ealing}

Not only employees have the opportunity to invoke the prohibition of discrimination. In the case of Dana Bidar v London Borough of Ealing The CJEU ruled that in terms of social benefits, an inactive EU citizen may invoke Art. 12 of the Treaty (Art. 18 TFEU), providing legal residence in a Member State for a certain period of time. The situation of a student legally residing in another Member State therefore falls within the scope of the Treaty within the meaning of Art. 12, first paragraph EC in the context of the eligibility for a maintenance grant ${ }^{59}$. However, national legislation requiring the status of an entity that has settled in the host state in order to receive support for subsistence costs in a situation of legal residence and effective integration into the host country's society is contrary to Art. 12 of the EC Treaty. Pursuant to Art. 4 of Student Support Regulations (British Education Regulation 2001) ${ }^{60}$, a student loan for certain studies may be used by a person who has settled in the United Kingdom under the Immigration Act 1971. It is apparent from the case that, under British legislation, a national of another Member State cannot, as a student, obtain the status of a person who has settled in the United Kingdom.

It should be emphasized that national standards make it impossible for citizens of other Member States to obtain the above status, thus precluding the possibility of obtaining the aid in question. This type of differentiation of the situation of own citizens and citizens of other countries has discriminatory features toward the latter group. It should be remembered that in the light of settled case law, the implementation of the principle of non-discrimination prohibits treating comparable situations differently ${ }^{61}$. Nevertheless, the ruling on Dana Bidar $v$ London Borough of Ealing and the ruling on Ruda Grzelczyk v Centre public d'aide

59 CJEU Judgement of 15 March 2005, Dany Bidar v London Borough of Ealing, Case C-209/03, ECLI:EU:C:2005:169, pt 37 and 42.

60 The Act on Education (Student Support) Regulations of 4 April 2001, Journal of Laws 2001, No. 174 as amended.

${ }^{61}$ CJEU Judgement of 3 May 2007, Advocaten voor de Wereld VZW v Leden van de Ministerraad, Case C-303/05, ECLI:EU:C:2007:261, pt 56. 
socjale d'Ottignies-Louvain-la-Neuve $e^{62}$ confirm the significant limitation in the competence of the Member States to grant cash benefits to migrant students ${ }^{63}$.

\subsection{Case European Commission v Republic of Austria}

In the case of European Commission v Republic of Austria ${ }^{64}$, many students who were nationals of Member States other than the Republic of Austria and wished to use public transport had to pay more than those paid by Austrian students. In some of the federated states, students within the meaning of $\$ \$ 3$ and 4 of Studienförderungsgesetz $1992^{65}$ in the version applicable at the time of the dispute, could benefit from concessionary fees only when their place of residence or the place of study was located on the premises of the public transport company concerned and when family allowances were received therein pursuant to Art. 2 of Familienlastenausgleichsgesetz (Law of 1967 on the equalization of the costs of maintaining the family through benefits, BGBl. No. 376/1967) ${ }^{66}$.

After analyzing the Commission's allegations against the Republic of Austria and the Austrian legal bases ${ }^{67}$ in relation to EU regulations ${ }^{68}$ The Court ruled that by reserving, in principle, the possibility of benefiting from the reduced fares only for students whose parents receive Austrian

62 CJEU Judgement of 20 September 2001, Rudy Grzelczyk v Centre public d'aide socjale d'Ottignies- Louvain- la- Neuve, Case C-184/99, ECLI:EU:C:2001:458.

63 See Aleksandra Czekaj-Dancewicz, "Rola orzecznictwa ETS w kształtowaniu wspólnotowego prawa do świadczeń finansowych na pokrycie kosztów kształcenia studentów," in Przeptyw osób i świadczenie ustug w Unii Europejskiej. Nowe zjawiska i tendencje, ed. Stanisław Biernat, Sławomir Dudzik (Warsaw: Wolters Kluwer Press, 2009), 142.

${ }^{64}$ CJEU Judgement of 4 October 2012, European Commission v Republic of Austria, Case C-75/11, ECLI:EU:C:2012:605.

65 Student Support Act ("Studienförderungsgesetz"), Journal of Laws 1992, No. 305/1992 (Austrian Federal Gazette BGBl.) as amended.

66 Act on the equalization of the costs of maintaining the family through benefits of 24 October 1967 (Familienlastenausgleichsgesetz), Journal of Laws 1967, No. 376/1967 (Austrian Federal Gazette BGBl.) as amended.

${ }^{67} \$ 3$ and 4 of Student Support Act ("Studienförderungsgesetz"), Journal of Laws 1992, No. 305/1992 (Austrian Federal Gazette BGBl.) as amended.

${ }_{68}$ Articles 18, 20, 21 TFEU and Art. 24 of Directive 2004/38/EC. 
family allowances, the Republic of Austria has failed to fulfill its obligations under Art. 18 TFEU in conjunction with Art. 20 TFEU and 21 TFEU and Art. 24 of Directive 2004/38/EC ${ }^{69}$. In fact, linking the toll reduction with the fact of receiving family allowances in the host Member State has the effect of discriminating against students from other Member States against national students. Such national legislation therefore remains in contradiction to the principles, which are the mainstay of EU citizenship.

In conflict with $\mathrm{EU} \mathrm{law}^{70}$ remain also national standards ${ }^{71}$, refusing to grant support for living costs during their studies to a national of another EU country studying in the host country and performing concurrently concrete and actual employment ${ }^{72}$. It is unfounded to say that the issue of benefits to cover the cost of living of migrant students does not fall within the scope of the Treaty. National provisions which make the granting of financial aid for higher education studies conditional on the fulfillment of a residence condition in the host country and differentiate treatment of residents of that country and non-residents who are children of frontier workers pursuing an activity in that country should also be viewed as discrimination in that Member State ${ }^{73}$.

\subsection{Case Commission of the European Communities v Republic of Austria}

In the case of Commission of the European Communities $v$ Republic of Austria $^{74}$ The Commission accused the Republic of Austria of lacking access to higher or university education for holders of a secondary education

69 CJEU Judgement of 4 October 2012, European Commission v Republic of Austria, Case C-75/11, ECLI:EU:C:2012:605, pt 67.

${ }_{70}$ Art. 7 sec. 1 letter c) and Art. 24 sec. 2 of Directive 2004/38/EC of the European Parliament and of the Council of 29 April 2004.

71 Article 2a (2) and 4 of the Danish Consolidated Act No. 661 of 29 June 2009 on public aid for education (L 95, Folketingstidende 2005/2006, appendix A, p. 2854).

72 CJEU Judgement of 21 February 2013, L.N. $v$ Styrelsen for Videregående Uddannelser og Uddannelsesstotte C-46/12, ECLI:EU:C:2013:97, pt 52.

73 CJEU Judgement of 20 June 2013, Elodie Giersch and others v État du GrandDuché de Luxembourg, Case C-20/12, ECLI:EU:C:2013:411, pt 84.

74 CJEU Judgement of 7 July 2005, Commission of the European Communities v Republic of Austria, Case C-147/03, ECLI:EU:C:2005:427. 
diploma obtained in another Member State on the same terms as persons who receive this kind of diploma in Austria. Paragraph 36 of the Universitäts Studiengesetz (Law on University Studies) ${ }^{75}$, entitled "Special Diploma for University Training" ("Besondere Universitätsreife"), states that it is not sufficient to present a high school diploma, but also to demonstrate that the conditions for access to university education have been met, competent for the given field of study, which means, inter alia, demonstrating the right of immediate admission to studies in the country that issued the certificate giving general right to access education during studies.

Thus, according to the Commission, Austria has failed to fulfill its obligations under Art. 12 of the EC Treaty (Article 18 TFEU) ${ }^{76}$. In the opinion of the CJEU, Austrian regulations differentiate the situation of people obtaining a diploma in Austria and abroad, because entities holding a secondary school diploma obtained in other Member States, in addition to the obligation to meet the general criteria for access to education, are obliged to prove that they meet the specific conditions for admission to the chosen field of study, established by the country that issued the diploma and allowing direct admission to these studies. Restricting access to education with additional conditions undoubtedly constitutes discrimination, even against Austrian citizens who hold a school diploma obtained in another Member State, although it will certainly more often apply to citizens of other Member States.

Undoubtedly, in accordance with settled case law, the principle of equal treatment prohibits not only overt discrimination on the basis of nationality but also hidden discrimination ${ }^{77}$. It should be considered that

75 Act on University Studies of 9 August 2002, Journal of Laws 2002, No. 121 as amended.

76 CJEU Judgement of 1 July 2004, Commission of the European Communities v Kingdom of Belgium, Case C-65/03, ECLI:EU:C:2004:402.

77 CJEU Judgement of 12 February 1974, Giovanni Maria Sotgiu v Deutsche Bundespost, Case C-152/73, ECLI:EU:C:1974:13, pt 11; CJEU Judgement of 1 July 2004, Commission of the European Communities v Kingdom of Belgium, Case C-65/03, ECLI:EU:C:2004:402, pt 28; CJEU Judgement of 15 March 2005, Dany Bidar v London Borough of Ealing, Case C-209/03, ECLI:EU:C:2005:169, pt 51; CJEU Judgement of 16 January 2003, Commission of the European Communities v Italian Republic, Case C-388/01, ECLI:EU:C:2003:30, pt 13; CJEU Judgement of 27 November 1997, H. Meints v Minister van Landbouw, Natuurbeheer en Visserij, Case C-57/96, 
the differentiation of the situation of persons in the above circumstances constitutes discrimination within the meaning of Art. 18 TFEU.

It follows from the jurisprudence of the CJEU that the application of a discriminatory measure is justified only in the exceptions listed in Art. 27 sec. 1 of Directive 2004/38/EC or in Art. 45 sec. 3 TFEU (Art. 39 (3) of the EC Treaty) ${ }^{78}$. Moreover, the implementation of restrictive measures obliges a member state to take steps in compliance with the principle of proportionality and relevance and to provide data confirming the state's $\operatorname{arguments}^{79}$. The Republic of Austria failed to meet the above conditions and did not guarantee equal access to the higher or university education system for nationals with a secondary education diploma obtained in an-

ECLI:EU:C:1997:564, pt 44; CJEU Judgement of 26 June 2001, Commission of the European Communities v Italian Republic, Case C-212/99, ECLI:EU:C:2001:357, pt 24; CJEU Judgement of 28 February 2013, Katja Ettwein v Finanzamt Konstanz, Case C-425/11, ECLI:EU:C:2013:121, pt 26; CJEU Judgement of 23 May 1996, John O’Flynn v Adjudication Officer, Case C-237/94, ECLI:EU:C:1996:206, pt 17, cit: “... the equal treatment rule laid down in Article 48 of the Treaty and in Article 7 of Regulation No1612/68 prohibits not only overt discrimination by reason of nationality but also all covert forms of discrimination which, by the application of other distinguishing criteria, lead in fact to the same result", see also: CJEU Judgement of 21 November 1991, Union de Recouvrement des Cotisations de Sécurité Sociale et d'Allocations Familiales de la Savoie (URSSAF) v Hostellerie Le Manoir SARL, Case C-27/91, ECLI:EU:C:1991:441, pt 10; CJEU Judgement of 10 March 1993, Case C-111/91, Commission of the European Communities v Grand Duchy of Luxembourg, ECLI:EU:C:1993:92, pkt 9; CJEU Judgement of 18 January 2007, Aldo Celozzi v Innungskrankenkasse Baden-Württemberg, Case C-332/05, ECLI:EU:C:2007:35, pt 22-23; CJEU Judgement of 25 June 1997, Carlos Mora Romero v Landesversicherungsanstalt Rheinprovinz, Case C-131/96, ECLI:EU:C:1997:317, pt 29; CJEU Judgement of 21 September 2000, Carl Borawitz v Landesversicherungsanstalt Westfalen, Case C-124/99, ECLI:EU:C:2000:485, pt 23; Justyna Maliszewska-Nienartowicz, "Zakaz dyskryminacji ze względu na płeć na rynku pracy- orzecznictwo Trybunału Sprawiedliwości WE," Studia Europejskie, Warsaw University Centre, no. 1 (2008): 78.

78 CJEU Judgement of 15 October 1969, Württembergische Milchverwertung-Südmilch AG v Salvatore Ugliola, Case C-15/69, ECLI:EU:C:1969:46; CJEU Judgement of 14 November 1995, Peter Svensson and Lena Gustavsson v Ministre du Logement et de l'Urbanisme, Case C-484/93, ECLI:EU:C:1995:379.

79 CJEU Judgement of 13 November 2003, Diana Elisabeth Lindman, Case C-42/02, ECLI:EU:C:2003:613, pt 25; CJEU Judgement of 18 March 2004, Ludwig Leichtle v Bundesanstalt für Arbeit, Case C-8/02, ECLI:EU:C:2004:161, pt 45. 
other Member State, and therefore failed to comply with the provisions of Art. 12 of the EC Treaty (Article 18 TFEU). Such an infringement will not, however, constitute a requirement of five years' prior residence in the territory of the host state in relation to nationals of other Member States who migrate to the latter to study and receive a grant for living expenses $^{80}$, since the host country has the right to refuse to grant subsistence aid to students who are not integrated into the host society ${ }^{81}$. However, it will not be able to do so if the student performs specific and actual work at the same time ${ }^{82}$.

In the social sphere, the prohibition of discrimination is contained in Art. 7 sec. 2 of Regulation 492/2011. This standard prohibits discrimination in social and tax areas ${ }^{83}$. In light of the previous jurisprudence of the CJEU, social privileges should not be interpreted restrictively ${ }^{84}$ because they contain in their content all the benefits granted to domestic workers due to the attribute of possessing employee status or due to the fact of residing in the territory of a given state. On the other hand, extending them to employees with citizenship of other Member States is aimed at supporting their mobility within the European Union ${ }^{85}$. In some Member States there are systemic obstacles, which are instances of unlawful

80 CJEU Judgement of 18 November 2008, Jacqueline Förster Hoofddirectie van Informatie Beheer Groep, Case C-158/07, ECLI:EU:C:2008:630, pt 72.

${ }^{81}$ Undoubtedly, the condition of prior residence differentiates the situation of students from other countries in relation to a country's own students. However, in the opinion of the CJEU, the above circumstances do not constitute discrimination, and the requirement of a five-year stay cannot be considered too burdensome or disproportionate.

82 Cf. CJEU Judgement of 21 February 2013, L.N. $v$ Styrelsen for Videregående Uddannelser og Uddannelsesstøtte C-46/12, ECLI:EU:C:2013:97.

83 Jo Carby-Hall, The treatment of Polish and other A8 economic migrants in the European Union Member States: a research programme prepared for Commisioner for Civil Right Protection of the Republic of Poland (Hull: University of Hull, 2008), 41.

84 CJEU Judgement of 27 November 1997, H. Meints v Minister van Landbouw, Natuurbeheer en Visserij, Case C-57/96, ECLI:EU:C:1997:564, pt 39.

85 CJEU Judgement of 14 January 1982, Francesco Rein, Letizia Rein v Landeskreditbank Baden-Württemberg, Case C-65/81, ECLI:EU:C:1982:6, pt 12; CJEU Judgement of 12 May 1998, Maria Martinez Sala v Freistaat Bayern, Case C-85/96, ECLI:EU:C:1998:217, pt 25; CJEU Judgement of 18 July 2007, Wendy Geven v Land Nordhein-Westfalen, Case C-213/05, ECLI:EU:C:2007:438, pt 12. 
discrimination. Most of them result from indirect discrimination or unjustified restrictions on the exercise of the right to free movement, for example, the requirement to reside in the host state, which is a condition for enjoying certain social or tax advantages ${ }^{86}$.

\subsection{Case Wendy Geven v Land Nordhein-Westfalen}

In the case of Wendy Geven $v$ Land Nordhein-Westfalen ${ }^{87}$, The CJEU ruled that the German Government had the right to refuse to grant a social advantage in the form of a childcare allowance under a national law, due to the applicant's lack of permanent or habitual residence in Germany. A national provision (section 1 (4) of the Bundeserziehungsgeldgesetz (Act on Childcare Benefits and Leave) $)^{88}$ provided for the right to childcare allowance for nationals of Member States and frontier workers from countries directly adjacent to Germany if they pursue in Germany a professional activity that does not constitute an additional occupation. In the presented case, the main question raised in the request for a preliminary ruling from the Bundessozialgericht is whether the additional occupation requirement, as defined in the national law, is compatible with Art. 7 sec. 2 of Regulation (EEC) No 1612/68 $8^{89}$, which guarantees equal treatment of migrant and national workers as regards the right to benefits.

The judgment of the CJEU seems to be fully justified, because it would be absurd to allow a frontier worker living and working in two different Member States, performing an additional activity, to use and combine the social benefits of both countries, especially since Regulation 1612/68/ EEC, unlike Regulation 492/2011, did not regulate the rules of coordination in the situation of overlapping cash benefits.

86 Stanisław Biernat, "Glosa do wyroku WSA w Warszawie z 20.11.2006r., I SA/Wa 1569/06, dotycząca wymogu zamieszkania i przebywania na terytorium Polski w celu uzyskania świadczeń na rzecz rodziny zastępczej," Orzecznictwo Sądów Polskich, no. 7/8 (2008).

87 CJEU Judgement of 18 July 2007, Wendy Geven v Land Nordhein-Westfalen, Case C-213/05, ECLI:EU:C:2007:438.

88 Act on Childcare Benefits and Leave of 4 February 2004, Journal of Laws 2004, No. 206 as amended.

89 Regulation (EC) of the Council No. 1612/68 on the free movement of workers within the Community (O.J.E.C. L 257, 15 October, 1968). 


\subsection{Case Gertraud Hartmann v Freistaat Bayern}

In the light of the ruling of the Court of Justice in the case of Jürgen Ritter-Coulais and Monique Ritter-Coulais v Finanzamt Germersheim ${ }^{90}$ any EU citizen, regardless of place of residence or nationality, who exercises the right to free movement of workers and pursues a professional activity in a Member State other than their country of residence, falls under the scope of application of Art. $45 \mathrm{TFEU}^{91}$. The question arises which rights granted by EU law can be exercised by an EU citizen if he or she moves to another Member State while remaining employed in the state of his or her previous residence. This issue was raised in the case of Gertraud Hartmann v Freistaat Bayern $^{92}$. The claimant, who is an Austrian national and the wife of a German national working in Germany, was refused a childcare allowance, arguing that she is not domiciled and does not pursue a professional activity in Germany. Bayerische Landessozialgericht (Bavarian National Social Security Court) found that both Mrs. Hartmann and her spouse were outside the scope of Regulation 1408/71/EEC of 14 June 1971, because pursuant to $\$ 1$ sec. 4 Bundeserziehungsgeldgesetz ${ }^{93}$, citizens of the European Union Member States and frontier workers from a country with a border with Germany are entitled to a childcare allowance, provided that they carry out professional activities in that Member State in excess of the minimum employment requirement.

It seems justified to say that the right of free movement of workers means migration to another country in order to perform professional activity there. However, the settlement of an entity in another Member State for purposes other than professional ones does not negate the attribute of a migrant worker and does not question being subject to the provisions of

90 CJEU Judgement of 21 February 2006, Jürgen Ritter-Coulais and Monique Ritter-Coulais v Finanzamt Germersheim, Case C-152/03, ECLI:EU:C:2006:123, pt 31-32.

91 CJEU Judgement of 7 July 2005, A. J. van Pommeren-Bourgondiën v Raad van bestuur van de Sociale verzekeringsbank, Case C-227/03, ECLI:EU:C:2005:431, pt 19,44 and 45 .

92 CJEU Judgement of 18 July 2007, Gertraud Hartmann v Freistaat Bayern, C-212/05, ECLI:EU:C:2007:437.

93 Act on Childcare Benefits and Leave of 4 February 2004, Journal of Laws 2004, No. 206 as amended. 
the Treaty and Regulation 1612/68/EEC. The immediate beneficiary of the rights is Mr. Hartmann, while his spouse may receive the allowance as long as it constitutes a social advantage for her husband. The German childcare allowance in the case of the Hartmann family is undoubtedly a social benefit in light of Art. 7 sec. 2 of Regulation 1612/68/EEC, regardless of the party requesting $\mathrm{it}^{94}$. However, the German legislature made the granting of this type of allowance subject to the requirement of residence in Germany, with the exception of frontier workers whose professional activity exceeds the minimum level of employment. Due to the fact that the condition relating to working time is met, the CJEU ruled on the entitlement to a childcare allowance in the presented case.

\subsection{Case Gemeinsamer Betriebsrat EurothermenResort Bad} Schallerbach GmbH v EurothermenResort Bad Schallerbach GmbH

In the this cases proceedings, the question whether Art. 45 TFEU and Art. 7 sec. 1 of Regulation No 492/2011 should be interpreted in the way that they are contrary to Art. 3 Urlaubsgesetz, which, in order to determine whether an employee who has worked for a total of 25 years is entitled to an increase in annual paid leave from five to six weeks, provides that the length of service acquired under one or more employment relationships preceding the employment relationship between him or her with his or her current employer can only be counted up to a maximum of five years, even if the actual length of service is more than five years.

Article 3 of Urlaubsgesetz ${ }^{95}$ limits to five years to take into account earlier periods of employment with other employers established in other Member States, which, according to the complainant, constitutes a restriction on the free movement of workers guaranteed by Art. 45 TFEU. The Court stated that Art. $45 \mathrm{sec} .2$ TFEU prohibits any discrimination on grounds of nationality between workers of the Member States as regards to employment, remuneration and other working conditions. Article $7 \mathrm{sec} .1$ of Regulation No 492/2011 is only a specific expression of the principle of

94 See also CJEU Judgement of 26 February 1992, M. J. E. Bernini v. Minister van Onderwijs en Wetenschappen, Case C-3/90, ECLI:EU:C:1992:89, pt 25-26.

95 Act on Austrian Holiday of 7 July 1976, Journal of Laws 1976, No. 390 as amended. 
non-discrimination guaranteed in Art. $45 \mathrm{sec} .2$ TFEU in the specific area of employment and working conditions, and therefore it should be interpreted in the same way as the latter provision ${ }^{96}$. The right to annual paid leave under Austrian law is, after 25 years of service, six weeks for the period of employment with the current employer. If the employee was previously employed by another or several other employers, only the period of employment with the latter of a maximum of five years in total may be taken into account. Thus, in order to be entitled to six weeks of paid annual leave, an employee must either work 25 years with the current employer or have worked for 25 years in total, including at least 20 years with the current employer. According to the settled case-law of Oberster Gerichtshof (Supreme Court) and the unanimous view of the doctrine, Article 3 of Urlaubsgesetz must be interpreted as meaning that periods of prior employment of a given employee with other employers are taken into account in the same way, that is to say, for a maximum of five years in total, irrespective of the fact whether they took place on the territory of the country or in another Member State. Given that such a rule applies without exception to all workers who have worked for at least 25 years, irrespective of their nationality, it does not constitute a source of discrimination based directly on nationality.

\section{CONCLUSIONS}

As shown by the numerous decisions of the CJEU, the transposition of EU regulations and the decision-making by competent authorities at the level of a given Member State are unsatisfactory. The problem is largely restrictive misinterpretation of the powers of EU citizens and their family members and the lack of appropriate mechanisms to facilitate the implementation of these rights. This thesis is even more confirmed by the activ-

96 CJEU Judgement of 5 December 2013, Zentralbetriebsrat der gemeinnützigen Salzburger Landeskliniken Betriebs GmbH $v$ Land Salzburg, Case C-514/12, ECLI:EU:C:2013:799, pt 23; CJEU Judgement of 26 October 2006, Commission of the European Communities v Italian Republic, Case C-371/04, ECLI:EU:C:2006:668, pt 17. 
ities of the European Commission, in particular in preventing discrimination on the basis of nationality of mobile EU workers ${ }^{97}$.

The concept aimed at optimizing the model was to be adjusted by the successive implementation of the regulation $s^{98}$, aimed at strengthening the protection of the rights and interests of citizens of the Member States, among others, by introducing the institution of EU citizenship, eliminating all forms of discrimination in terms of employment and working conditions, or eliminating internal border controls.

Exploration of CJEU jurisprudence confirms the application and implementation of national provisions in the field of the principle of equal treatment in a manner that demonstrates their disproportion with the norms of EU law. An important factor causing the dissonance in question is, first of all, the creation of national regulations inconsistent with EU law. This poses a high risk of using them in practice, in a serial way for a large number of recipients. The rulings of the CJEU are largely the result of preliminary questions from judicial and administrative authorities applying national law. All the more significant seems to be their role in the matter under discussion. An additional difficulty in the implementation of the principle of equal treatment is reflected in the fact that it covers many spheres of life. This makes it practically impossible to verify, in terms of compliance with EU regulations, administrative acts relating in some part to the issue of non-discrimination. This, in turn, gives rise to conclusions in the form of an opinion, balancing on the verge of certainty, that principle in question is mostly implemented in a manner inconsistent with the TFEU and secondary law. The most accurate determinant of this theory is the scale of the CJEU jurisprudence.

Following the jurisprudence of the CJEU, it should be stated that the differences and discrepancies in the manner of application and en-

97 In April 2013, the Commission presented a proposal for a Directive of the European Parliament and of the Council on measures to facilitate the exercise of the rights granted to workers in the context of the free movement of workers, COM (2013) 236. The directive itself entered into force on 20 May 2014, Journal of Laws No. L 128, p. 8, 30/04/2014.

98 On the evolution of legal regulations in the field of freedom of migration, see Chapter I, point 1- The legal basis of the free movement of workers within the Community and the directions of changes in the development of the free movement of workers in the European Union. 
forcement of the provisions of EU law, occurring in the national legal systems of the Member States, have a negative impact on the proper functioning of the principle of non-discrimination in their territories. It is undoubtedly very difficult to ensure equal opportunities and treatment for EU citizens when exercising their right to free movement, but all the more the standard of legal clarity and certainty in this area should be achieved at the EU level.

The jurisprudence of the Court implies an obligation for courts and other authorities of the Member States to interpret domestic law in accordance with EU law, its content and purpose, and therefore they are obliged, as far as possible, to interpret national law in the light of the provisions of EU law in order to guarantee the result envisaged therein. As the analysis of the CJEU's decisions shows, the authorities and courts of the Member States do not play this role, which results in violations of subjective rights in the matter in question.

To sum up, undoubtedly the analysis of the decisions of the Court of Justice of the European Union in conjunction with the supervision of the process of transposition of EU provisions into national legal orders leads to the conclusion that permanent revision of legislative acts and administrative practices, contrary to EU law and CJEU jurisprudence in the field of non-discrimination principle due to nationality is fully justified.

\section{REFERENCES}

Babayev, Rufat. Choice of the applicable law and equal treatment in the European Union. Durham: Durham University, 2012.

Biernat, Stanisław. "Glosa do wyroku WSA w Warszawie z 20.11.2006r., I SA/

Wa 1569/06, dotycząca wymogu zamieszkania i przebywania na terytorium Polski w celu uzyskania świadczeń na rzecz rodziny zastępczej." Orzecznictwo Sąów Polskich, no. 7/8 (2008): 581-585.

Brouwer, Evelien, and Karin de Vries. "Third-country nationals and discrimination on the ground of nationality:article 18 TFEU in the context of article 14 ECHR and EU migration law: time for a new approach." In Equality 
and human rights: nothing but trouble?, edited by Marjolein Van den Brink, Susanne Burri, and Jenny Goldschmidt, 123-146. Utrecht: SIM, 2015.

Carby-Hall, Jo. The treatment of Polish and other A8 economic migrants in the European Union Member States: a research programme prepared for Commisioner for Civil Right Protection of the Republic of Poland. Hull: University of Hull, 2008. Cottier, Thomas, and Matthias Oesc. "Direct and Indirect Discrimination in WTO Law and EU Law." Working Paper, no. 2011/16 (April 2011): 1-25.

Czapliński, Władysław. Zarys prawa europejskiego. Warsaw: Hesińska Fundacja Praw Człowieka, 1999.

Czekaj, Aleksandra. "Glosa do orzeczenia ETS z dnia 17.09.2002r. w sprawie C413/99, Baumbast i R. v Secretary of State for the Home Department." Problemy Wspótczesnego Prawa Międzynarodowego, Europejskiego i Porównawczego 2 (2004): 186-202.

Czekaj-Dancewicz, Aleksandra. "Rola orzecznictwa ETS w kształtowaniu wspólnotowego prawa do świadczeń finansowych na pokrycie kosztów kształcenia studentów." In Przeptyw osób i świadczenie ustug w Unii Europejskiej. Nowe zjawiska $i$ tendencje, edited by Stanisław Biernat, and Sławomir Dudzik, 132-153. Warsaw: Wolters Kluwer, 2009.

Ellis, Evelyn. "Social advantages: a new lease of life?." Common Market Law Review 40 (2003): 639-659.

Florek, Ludwik. Europejskie prawo pracy. Warsaw: LexisNexis Press, 2010.

Goodwin-Gill, Guy S. "Migration: International Law and Human Rights." In Managing Migration: Time for a New International Regime?, edited by Bimal Gosh, 160-189. Oxford: Oxford University Press, 2000.

Górski, Marek. "Wpływ orzecznictwa Europejskiego Trybunału Sprawiedliwości na interpretację i stosowanie przepisów o ochronie środowiska." In Wspólnotowe prawo ochrony środowiska i jego implementacja w Polsce trzy lata po akcesji, edited by Jerzy Jendrośka, and Magdalena Bar, 31-46. Wrocław: Centrum Prawa Ekologicznego Press, 2008.

Kolasiński, Marek Krzysztof. "Odmienności związane z zatrudnieniem w administracji publicznej." In Zarys prawa swobód rynku wewnętrznego Unii Europejskiej, edited by Marek Krzysztof Kolasiński, 213-234. Toruń: Dom Organizatora Press, 2013.

Maliszewska-Nienartowicz, Justyna. "Rola zasady równości w prawie Wspólnoty/ Unii Europejskiej.” Studia Europejskie, no. 4 (2011): 73-94.

Maliszewska-Nienartowicz, Justyna. "Zakaz dyskryminacji ze względu na płeć na rynku pracy- orzecznictwo Trybunału Sprawiedliwości WE.” Studia Europejskie, Warsaw University Centre, no. 1 (2008): 75-94. 
McCrudden, Christopher, and Sacha Prechal. The concepts of Equality and non-discrimination in Europe. A practical Approach. Brussels: European Network of Legal Experts in the Field of Gender Equality, 2009.

Mitrus, Leszek. "Ewolucja prawa unijnego w dziedzinie swobody przemieszczania pracowników." In Prawo pracy w świetle procesów integracji europejskiej. Księga jubileuszowa Profesor Marii Matey-Tyrowicz, edited by Jerzy Wratny, and Magdalena Barbara Rycak, 125-141. Warsaw: Wolters Kluwer, 2011.

Mitrus, Leszek. Swoboda przemieszczania się pracowników po przystapieniu Polski do Unii Europejskiej. Cracow: LexisNexis Press, 2003.

Morano-Foadi, Sonia. "Third Country Nationals Versus EU Citizens: Discrimination Based on Nationality and the Equality Directives." Oxford Brookes University - School of Social Sciences and Law (December 2010): 1-26.

Niedźwiedź, Monika. "Stosowanie prawa wspólnotowego przez organy administracyjne." Casus, no. 32 (October 2004): 6-11.

Pennings, Frans. "Non-Discrimination on the Ground of Nationality in Social Security: What are the Consequences of the Accession of the EU to the ECHR?." Utrecht Law Review 9, Issue 1 (January 2013): 118-134.

Rossi Dal Pozzo, Francesco. Citizenship rights and freedom of movement in the European Union. the Netherlands: Kluwer Law International Press, 2013.

Schutter, Olivier. Links between migration and discrimination. A legal analysis of the situation in EU Member States. Brussels: European Commission, 2016.

Smusz-Kulesza, Monika. "Ograniczenia swobody przepływu pracowników." In Swobodny przeptyw pracowników wewnątrz Unii Europejskiej, edited by Zbigniew Hajn, 98-127. Warsaw: Instytut Wydawniczy EuroPrawo Press, 2010. Sundberg-Weitman, Brita. Discrimination on Grounds of Nationality. Free Movement of Workers and Freedom of Establishment under the EEC Treaty. Amsterdam, New York, Oxford: North-Holland Publishing Co., 1977.

Szyszczak, Erica. "Antidiscrimination Law in the European Union." Fordham International Law Journal, no. 32 (2008): 531-550.

Van der Mei, Anne. "The Outer Limits of the Prohibition of Discrimination on Grounds of Nationality: A Look through the Lens of Union Citizenship." Maastricht Journal of European and Comparative Law 18, Issue 1-2 (March 2011): 62-85.

Zawidzka - Łojek, Anna. Zakaz dyskryminacji ze względu na wiek w prawie Unii Europejskiej. Warsaw: Instytut Wydawniczy EuroPrawo, 2013. 